\title{
Konsepsi Peran Guru Sebagai Fasilitator dan Motivator Dalam Proses Pembelajaran Pendidikan Agama Islam
}

\author{
Ali Mustofa \\ Prodi Pendidikan Agama Islam \\ Sekolah Tinggi Ilmu Tarbiyah Al Urwatul Wutsqo Jombang \\ e-mail: aljep_90@yahoo.com \\ Arif Muadzin \\ Prodi Pendidikan Agama Islam \\ Sekolah Tinggi Ilmu Tarbiyah Al Urwatul Wutsqo Jombang
}

\begin{abstract}
Facilities and motivation in learning are very important. This study discusses the role of the teacher as a facilitator and motivator in the learning process of Islamic religious education. The purpose of this study was to determine the role of the teacher as a facilitator and motivator, and the inhibiting factors in its implementation. To get answers to the problems above, the authors conducted qualitative research. After analyzing the data obtained, the results showed the readiness of the teacher, namely: The teacher provides all learning tools before learning begins (such as syllabus, curriculum, lesson plans, evaluation materials and teaching materials). ), Teachers provide learning facilities in the form of methods, media, and learning equipment, Teachers as partners not superiors and teachers do not act arbitrarily to students, and teachers are able to understand students well and provide learning experiences that are appropriate for students and intrinsically motivating. All of this can be achieved through a good understanding of a teacher regarding teacher theory as a facilitator and motivator. All aspects of education, the family and community environment should be in line with and support the teacher's role as a facilitator and motivator so that it can be realized properly.
\end{abstract}

Keywords: Role, Facilitator, Motivator, Learning

\section{Pendahuluan}

Undang-Undang Nomor 20 tahun 2003 tentang Sistem Pendidikan Nasional, pendidikan sebagai usaha sadar dan terencana untuk mewujudkan suasana belajar dan proses pembelajaran agar peserta didik secara aktif mengembangkan potensi dirinya untuk memiliki kekuatan spiritual keagamaan, pengendalian diri, kepribadian, kecerdasan, akhlak mulia, serta keterampilan yang di perlukan dirinya , masyarakat bangsa dan negara (UU 2003:20).

Selanjutnya Undang - Undang Nomor 14 tahun 2005 tentang Guru dan Dosen pada pasal 1 ayat 1 menyatakan bahwa guru adalah pendidik profesional dengan tugas utama mendidik, mengajar, membimbing, mengarahkan, melatih, menilai, dan mengevaluasi peserta didik pada pendidikan anak usia dinijalur pendidikan formal, pendidikan dasar, dan pendidikan menengah.

Berbagai beban yang harus diemban dari seorang guru seperti apa yang di amanatkan kepadanya melalui peraturan-peraturan yang ada tidak serta merta membuat guru menjadi 
putus asa. Justru sebaliknya posisinya yang strategis bisa di jadikan guru untuk lebih mengkualitaskan perannya menjadi lebih baik lagi.

Undang-Undang di atas dapat kita ambil kesimpulan bahwa guru bersifat sebagai fasilitator, yaitu bagaimana guru bisa menghadirkan suasana belajar yang mengasikan. Proses pembelajaran yang aktif, interaktif, partisipatif dan inovatif di harapkan dapat membuka jalan bagi berkembangnya keterampilan dan potensi diri serta kepribadian yang baik.

Supaya pembelajaran berjalan dengan efektif, guru di harapkan dapat memberikan kesempatan kepada peserta didik untuk terlibatkan secara aktif dalam proses pembelajaran. Pengalokasian waktu mengajar yang banyak dan optimal di harapkan dapat di gunakan guru untuk membangkitkan motivasi dan minat peserta didik untuk belajar.

Dalam proses pembelajaran yang terlihat bukan hanya kenyataan ril dan konsep, tetapi juga akan melibatkan perasaan-perasaan, seperti kasih sayang, dengki, benci dan lain sebagainya. Pembelajaran tidak hanya sebatas rencana atau rancangan tetapi lebih kepada pengalaman penuh atas kesadaran pribadi, yang melibatkan alat indra kita. Pembelajaran adalah suatu proses yang di lakukan oleh individu untuk memperoleh suatu perubahan perilaku yang baru secara menyeluruh, sebagai hasil dari pengalaman individu itu sendiri dalam berinteraksi dalam lingkungannya (Surya, 2004).

Sebagai fasilitator, guru di harapkan berperan dalam menyumbangkan pelayanan yang prima termasuk menyediakan fasilitas demi memberi kemudahan dalam proses kegiatan belajar bagi anak didik. Lingkungan belajar yang rapih, suasana yang menyenangkan, sirkulasi udara yang baik dan meja serta kursi yang tertata rapih bisa di pastikan murid semangat dalam belajar. Maka dari itu guru di harapkan mampu menyediakan fasilitas yang memadai sehingga proses pembelajaran bisa menjadi menyenangkan serta mengasyikan bagi peserta didik.

Hal-hal yang perlu di perhatikan terkait dengan sikap dan guru sebagai fasilitator yaitu: Mendengarkan dan tidak mendominasi, bersikap sabar, menghargai dan rendah hati, mau belajar, bersikap sederajat, bersikap akrab dan melebur, tidak berusaha menceramahi, berwibawa, tidak memihak dan mengkritik, bersikap terbuka, serta bersikap positif (Sindhunata, 2001).

Terkait dengan guru sebagai fasilitator terdapat pola hubungan kemitraan antara guru dengan peserta didik, yaitu guru bertindak sebagai pembimbing belajar dalam proses pembelajaran dengan suasana belajar yang merdeka dan demokratis serta menyenangkan. Guru dapat menjalankan perannya sebagai fasilitator seyogyanya guru dapat memenuhi prinsip-prinsip belajar yang di kembangkan dalam pendidikan kemitraan, yaitu peserta didik 
akan belajar dengan baik apabila: Peserta didik secar penuh dapat mengambil bagian dalam setiap aktivitas pembelajaran, apa yang di pelajari bermanfaat dan praktis, peserta didik memunyai kesempatan untuk memanfaatkan secara penuh pengetahuan dan keterampilannya dalam waktu yang cukup, pembelajaran dapat mempertimbangkan dan di sesuaikan dengan pengalaman - pengalaman sebelumnya dan daya pikir peserta didik, dan terbina saling pengertian baik antara guru dengan peserta didik maupun peserta didik dengan peserta didik (Sanjaya, 2008).

Selain sebagai fasilitator guru juga memiliki peran yang tidak kalah penting dalam membangun motivasi peserta didik, terutama motivasi dalam kegiatan belajar. Untuk melakukan kegiatan tersebut guru harus memahami peserta didik dengan baik, dan menyediakan pengalaman pembelajaran yang sesuai dengan peserta didik. Melalui pemahaman yang baik tentang peserta didik, guru mampu mendorong peserta didik menemukan sesuatu yang menarik, bernilai, dan secara instrinsik memotivasi, menantang dan berguna bagi peserta didik (Priansa, Menjadi Kepala Sekolah dan Guru Profesional, 2017).

Dalam beberapa terminologi, motivasi dinyatakan sebagai suatu kebutuhan (need), keinginan (wants), gerak hati (impulse), naluri (instincts), dan dorongan (drive), yaitu sesuatu yang memaksa organisme manusia untuk berbuat atau bertindak. Motivasi adalah suatu konsep yang di gunakan untuk menjelaskan inisiasi, arah dan intensitas perilaku individu (Khadijah, 2011).

Motivasi belajar yaitu keseluruhan daya penggerak psikis di dalam diri siswa yang menimbulkan kegiatan belajar, menjamin kelangsungan kegiatan belajar dan memberi arah pada kegiatan belajar itu demi mencapai suatu tujuan (Winkel, 2005). Motivasi belajar memegang peranan penting dalam memberikan gairah atau semangat dalam belajar, sehingga siswa yang bermotivasi kuat memiliki energi banyak untuk melakukan kegiatan belajar. Berdasar pendapat - pendapat yang di kemukakan dia atas dapat kita tarik kesimpulan bahwa motivasi belajar adalah suatu penggerak yang timbul dari kekuatan mental diri peserta didik maupun diri penciptaan kondisi belajar sedemikian rupa untuk mencapai tujuan-tujuan belajar itu sendiri.

Pendidikan Agama Islam adalah "pendidikan yang memberikan pengetahuan dan membentuk sikap, kepribadian dan keterampilan peserta didik dalam mengamalkan ajaran agama islam, yang di laksanakan sekurang-kurangnya melalui mata pelajaran pada semua jenjang pendidikan" (KEMENAG, 2011: No.211). Sedangkan mata pelajaran Pendidikan Agama Islam menurut keputusan menteri No.211 meliputi “al-Quran/Hadis, aqidah/keimanan, tarikh/Sejarah Kebudayaan Islam, dan fiqih” (KEMENAG, 2011: No.211). 
Oleh karenanya Pendidikan Agama Islam sangatlah penting bagi peserta didik serta manusia seluruhnya. Dengan adanya Pendidikan Agama Islam di harapkan para siswa memiliki akhlak yang sesuai dengan ajaran Islam, serta aktif dalam beribadah.

\section{Pembahasan}

\section{Guru}

\section{Pengertian guru}

Guru adalah pendidik, yaitu orang dewasa yang bertanggung jawab memberi bimbingan atau bantuan kepada peserta didik dalam perkembangan jasmani dan rohani agar mencapai kedewasaannya (Jamaludin, 1978).

Dalam konteks pendidikan Islam secara etimologi guru di sebut dengan murabbi, muallim, dan muaddib (Ramayulis, 2011). Secara terminologis, para pakar menyebutkan makna pengertian tentang guru secara berbeda - beda, antar lain:

a. Ahmad Tafsir mengatakan bahwa guru dalam Islam sama dengan teori Barat, yaitu siapa saja yang bertanggung jawab terhadap perkembangan peserta didik.

b. Zakia Dradjat berpendapat bahwa guru adalah individu yang akan memenuhi kebutuhan pengetahuan, sikap dan tingkah laku peserta didik.

c. Moh. Fadhil al-Djamil menyebutkan, bahwa guru adalah orang yang mengarahkan manusia kepada kehidupan yang baik sehingga terangkat derajat kemanusiaanya sesuai dengan kemampuan dasar yang di miliki oleh manusia.

Jadi guru adalah suri tauladan yang mengajarkan kepada peserta didik apa yang belum di ketahui oleh mereka dan seorang yang memikul tanggung jawab pendidikan yang terpikul di pundak para orang tua untuk memberikan ilmu pengetahuan, mempengaruhi peserta didik untuk mencapai suatu kedewasaan, bertingkah laku yang baik dalam kehidupan. Dari arahan sorang guru sehingga peserta didik terarah menjadi pribadi yang baik maka Allah SWT akan meninggikan derajat kemanusiaannya sesuai dengan kemampuannya hingga beberapa derajat di mata Allah SWT.

Allah SWT berfirman di dalam surat Al-Mujadallah ayat 11 yang berbunyi:

11. Hai orang-orang beriman apabila kamu dikatakan kepadamu: "Berlapanglapanglah dalam majlis", Maka lapangkanlah niscaya Allah akan memberi kelapangan untukmu. dan apabila dikatakan: "Berdirilah kamu", Maka berdirilah, niscaya Allah akan meninggikan orang-orang yang beriman di antaramu dan orang-orang yang diberi ilmu pengetahuan beberapa derajat. dan Allah Maha mengetahui apa yang kamu kerjakan (Al-Quran dan terjemah Al Hadi, 2015).

Guru adalah pendidik profesional dengan tugas utama mendidik, mengajar, membimbing, mengarahkan, melatih, menilai, dan mengevaluasi peserta didik pada 
pendidikan anak usia dini jalur pendidikan formal, pendidikan dasar, dan pendidikan menengah (UU, 2005).

Secara psikologis, belajar merupakan "suatu proses perubahan yaitu perubahan tingkah laku sebagai hasil interaksi dengan lingkungannya dalam memenuhi kebutuhan hidupnya" (Kosmiyah, 2012).

Pengertian belajar menurut pendapat para ahli, ialah sebagai berikut:

a. Menurut Hintzman yang dikutip oleh Muhibbin Syah

"Learning is a change in organism due to experince which can affec the organism 's behavior". Artinya, belajar adalah suatu perubahan yang terjadi dalam diri oragnisme (manusia dan hewan) disebabkan oleh pengalaman yang dapat mempengaruhi tingkah laku organisme tersebut (Syah, 2014).

b. Menurut Sadiman yang dikutip M. Faturrahman

Belajar adalah "suatu proses yang kompleks yang terjadi pada semua orang dan berlangsung seumur hidup, sejak dia masih bayi hingga keliang lahat" (Sulistyirini, 2012).

c. Menurut Alsa yang dikutip Nur Ghufron

Belajar adalah "tahapan perubahan perilaku individu yang relatif menetap sebagai hasil pengalaman dan interaksi individu dengan lingkungan” (Ghufron, 2013).

Dari pendapat yang di kemukakan oleh para ahli di atas dapat kita simpulkan bahwa belajar adalah suatu proses perubahan yang terjadi dari akibat pengetahuan, pengalaman, dan keterampilan seseorang baik dari segi jasmani maupun rohani.

Adapun pengertian Pendidikan Agama Islam yang tercantum dalam keputusan menteri agama republik Indonesia nomor 211 tahun 2011 tentang pedoman pengembangan agama Islam pada sekolah, bahwa Pendidikan Agama Islam adalah upaya menyiapkan peserta didik untuk mengenal, memahami, mengahayati, mengimani, dan mengamalkan ajaran dan nilai-nilai agama Islam dari sumber utamanya: kitab suci alQur'an dan Hadis, melalui kegiatan bimbingan, pengajaran, latihan dan penggunaan pengalaman, disertai tuntutan untuk menghormati pemeluk agama lain dalam hubungannya dengan kerukunan inter dan antar umat beragama sehingga terwujud persatuan dan kesatuan bangsa (KEMENAG, 2011).

Sedangkan Pengertian Pendidikan Agama Islam menurut pendapat para ahli ialah:

a. Menurut Ramayulis

Pendidikan Agama Islam adalah upaya sadar dan terencana dalam menyiapkan peserta didik untuk mengenal, memahami, menghayati, mengimani, bertakwa 
berakhlak mulia, mengemalkan ajaran agama Islam dari sumber utmanya kitab suci al- Qur'an dan al-Hadist, melalui kegiatan bimbingan, pengajaran latihan, serta penggunaan pengalaman (Ramayulis, 2005).

b. Menurut Achmadi

Pendidikan Agama Islam adalah "usaha yang lebih khusus ditekankan untuk mengembangkan fitrah keberagamaan (religiousitas) subyek didik agar lebih mampu memahami, menghayati, dan mengamalkan ajaran-ajaran Islam" (Achmadi, 2005).

c. Menurut Abdurrahman an-Nahlawi yang dikutip Tohirin

Pendidikan Agama Islam adalah "penataan individual dan sosial yang dapat menyebabkan seseorang tunduk taat pada Islam dan menerapkannya secara sempurna di dalam kehidupan individu dan masyarakat" (Tohirin, 2011).

Dari beberapa pengertian para ahli di atas dapat kita simpulkan bahwa Pendidikan Agama Islam adalah suatu cara atau usaha untuk mewujudkan manusian yang hidup Islami, yaitu yang berpedoman pada norma agama Islam serta mempersiapkan peserta didik untuk dapat memahami, menghayati, serta mengamalkan ajaran agama Islam secara totalitas berdasarkan sumber utamanya yaitu al-Quran dan Hadis. 


\section{Macam - Macam Peran Guru}

Menurut Tampubolon (2001) menyatakan peran guru peran guru bersifat multifungsional, yaitu guru berperan sabagai:
a. Orang tua
b. Pendidik atau pengajar
c. Produsen atau pelayan
d. Pembimbing atau fasilitator
e. Motivator atau stimulator
f. Peneliti atau narasumber

Peran tersebut dapat bergradasi menurun, naik, atau tetrap sesuai dengan jenjang tuntutannya (Suprihastiningrum, 2013).

Sedangkan menurut Hamalik, guru dapat melaksanakan perannya yaitu :

a. Sebagai fasilitator, yang menyediakan kemudahan - kemudahan bagi siswa untuk melakukan kegiatan belajar,

b. Sebagai pembimbing, yang membantu siswa mengatasi kesulitan dalam proses belajar,

c. Sebagai penyedia lingkungan yang berupaya menciptakan lingkungan yang menantang siswa agar melakukan kegiatan belajar,

d. Sebagai komunikator, yang melakukan komunikasi dengan siswa dan masyarakat,

e. Sebagai model, yang mampu memberi contoh yang baik kepada siswanya gar berperilaku yang baik,

f. Sebagai evaluator, yang melakukan penilaian terhadap kemajuan belajar siswa,

g. Sebagai inovator, yang turut menyebarluaskan usaha- usaha pembaruan kepada masyarakat,

h. Sebagai agen moral dan politik, yang turut membina moral masyarakat, peserta didik serta menunjang upaya - upaya pembangunan,

i. Sebagai agen kognitif, yang menyebarkan ilmu pengetahuan kepada peserta didik dan masyarakat,

j. Sebagai manajer,yang memimpin kelompok siswa dalam kelas sehingga proses pembelajaran berhasil (Hamalik, 2008).

Dari penjelasan di atas dapat kita ketahui bahwa peran seorang guru sangatlah penting dalam pendidikan, karena guru mampu mengatasi kesulitan yang di alami peserta didik dalam proses belajar serta memberikan contoh yang baik kepada siswanya dan 
berupaya menghadirkan suasana belajar yang mengasikan dan tidak lain kalau bukan seorang guru.

\section{Peran Guru Sebagai Fasilitator}

Guru sebagai fasilitator artinya guru memfasilitasi proses pembelajaran. Fasilitator bertugas mengarahkan, memberi arah, memfasilitasi kegiatan belajar peserta didik, dan memberikan semangat.

Guru sebagai fasilitator juga berarti guru berperan memfasilitasi kegiatan pembelajaran dalam rangka mencapai tujuan pendidikan. Guru sebagai fasilitator tugasnya bukan hanya mengajar melainkan membina, membimbing, memotivasi, serta memberikan penguat - penguat positif kepada peserta didik.

Menurut Wina Sanjaya, peran guru sebagai fasilitator yaitu : Guru berperan memberikan pelayanan untuk memudahkan peserta didik dalam kegiatan proses pembelajaran (Sanjaya, 2008).

Teori di atas memberikan gambaran kepada kita bahwa guru sebagai fasilitator membawa dampak pada pola hubungan antara guru dengan peserta didik menjadi hubungan kemitraan, yang semula bersifat "top - Down" (atas-bawah) yaitu guru seringkali di posisikan sebagai atasan yang cenderung otoriter, instruksi bergaya birokrat, bahkan pawang. Sedangkan peserta didik di posisikan sebagai bawahan yang senantiasa patuh terhadap instruksi dan segala sesuatu yang di kehendaki oleh guru. Peran guru agama sebagai fasilitator yaitu guru memiliki tugas memberikan bimbingan serta arahan bagi proses pembelajaran di kelas. Sebagai frasilitator, guru agama juga berperan sebagai pemandu jalannya diskusi, yakni meliputi bimbingan belajar dan bimbingan perkembangan sikap keagamaan peserta didik.

\section{Indikator Guru sebagai Fasilitator}

Indikator yaitu ciri atau penanda sesuatu itu berjalan atau berhasil atau berjalan dengan baik atau tidak. Indikator sangat penting untuk mengetahui dan mengukur sesuatu, termasuk mengukur peran guru sebagai fasilitator. Ada lima indikator keberhasilan guru sebagai fasilitator menurut Wina Sanjaya, yaitu :

a. Guru menyediakan seluruh perangkat pembelajaran sebelum pembelajaran di mulai (seperti silabus, kurikulum, RPP, bahan evaluasi dan bahan)

b. Guru menyediakan fasilitas pembelajaran berupa metode, media, serta peralatan belajar

c. Guru bertindak sebagai mitra, bukan atasan 
d. Guru melaksanakan tugas dan fungsinya yang telah di tentukan dalam undang undang

e. Guru tidak bertindak sewenang-wenang kepada peserta didik (Sanjaya, 2008).

\section{Sebelas peran Guru sebagai Fasilitator}

Guru pada saat ini bukan lagi sebagai satu - satunya sumber informasi bagi peserta didik. Tapi pada kenyataan yang ada di lapangan guru masih sering kali menjadi sumber utama informasi dan pembelajaran cenderung berpusat pada guru. Guru untuk saat ini harus berperan sebagai fasilitator yaitu di maksudkan agar kelas menjadi lebih hidup dan bergairah. Praktik pembelajaran dengan melulu ceramah harus di ganti dengan pembelajaran yang mengaktivkan peserta didik. Terkait dengan sikap dan perilaku guru sebagai fasilitator, di bawah ini dapat diuraikan peran guru sebagai fasilitator di lapangan (Agustina, 2017).

a. Guru kurang mendengarkan dan mendominasi

Peserta didik merupakan pelaku utama, maka sebagai fasilitator guru harus memberi kesempatan agar peserta didik aktif. Langkah ini tidak terlalu mudah karena masih banyak guru yang kurang mendengarkan peserta didik dan masih mendominasi di kelas.

b. Guru kurang sabar

Pembelajaran adalah aspek utama dalam proses belajar yang dilakukan oleh peserta didik itu sendiri, jika guru kurang sabar melihat proses yang kurang lancar lalu mengambil alih proses itu, maka hal ini sama saja dengan merampas kesempatan belajar peserta didik.

c. Guru kurang menghargai dan kurang rendah hati

Guru berupaya mungkin untuk menghargai siswa dengan menunjukan minat yang sungguh-sungguh pada pengetahuan dan pengalaman mereka. Tapi kebanyakan guru kurang menghargai peserta didik dan kurang bersikap rendah hati dalam menghadapi peserta didik.

d. Guru kurang mau sejajar

Seorang guru tidak akan dapat bekerja sama dengan peserta didik apabila dia tidak ingin memahami atau belajar tentang mereka. Kebanyakan guru masih kurang keinginan untuk belajar.

e. Kurang bersikap sederajat 
Guru perlu mengembangkan sikap kesederajatan agar bisa di terima sebagai teman atau mitra kerja oleh peserta didiknya. Tapi yang menjadi penghambat yaitu sikap guru yang merasa ingin di gugu dan di tiru.

f. Guru yang berusaha menceramahi

Peserta didik memiliki pengalaman, pendirian, dan keyakinan tersendiri. Oleh karena itu, guru tidak perlu menunjukan diri sebagai orang yang tahu, tetapi berusaha untuk saling berbagi pengalaman dengan peserta didiknya, sehingga di peroleh pemahaman yang kaya di antara keduanya.

g. Berwibawa

Meskipun pembelajaran harus berlangsung dalam suasana yang akrab dan santai, seorang fasilitator sebaiknya tetap dapat menunjukan kesungguhan di dalam bekerja dengan peserta didiknya, sehingga peserta didik akan tetap menghargainya.

h. Tidak memihak dan mengkritik

Di tengah kelompok peserta didik sering kali terjadi pertentangan pendapat. Dalam hal ini guru berupaya bersikap netral dan berusaha memfasilitasi komunikasi di antara pihak-pihak yang berbeda pendapat, untuk mencari kesepakatan dan jalan keluarnya.

i. Guru kurang terbuka

Peserta didik biasanya akan lebih terbuka apabila tumbuh telah kepercayaan kepada guru yang bersangkutan. Oleh karena itu, guru juga jangan segan untuk berterus terang bila merasa kurang mengetahui sesuatu, agar siswa memahami bahwa semua orang perlu belaja.

j. Guru bersikap negatif

Guru mengajak peserta didik untuk memahami keadaan dirinya dengan menonjolkan potensi-potensi yang ada, bukan sebaliknya mengeluhkan keburukan-keburukannya. Perlu di ketahui, bahwa Allah tidak akan merubah keadaan suatu kaum sebelum kaum itu mau merubah apa yang ada pada dirinya.

\section{Faktor penghambat Peran Guru sebagai Fasilitator}

a. Faktor kurangnya pengalaman

Kurangnya pengalaman menerapkan teori guru sebagai fasilitator, karena peran sebagai fasilitator ini tidak mudah terkadang guru masih menjalankan peran lamanya seperti mendominasi kelas, kurang memberi ruang kepada semua peserta untuk memberi tanggapan. 
b. Faktor kurangnya wawasan guru mengenai teori guru sebagai fasilitator Faktor penghambat ke dua ini yaitu masih kurangnya wawasan dan Sinformasi mengenai tugas dan fungsi guru sebagai fasilitator. Ini berdampak pada kurang luwesnya guru dalam mengaplikasikan teori peran guru sebagai fasilitator. Guru kadang - kadang masih terlihat kaku, kurang percaya diri ketika memfasilitasi peserta didik di kelas.

c. Faktor minimnya fasilitas sekolah

Sudah menjadi rahasia umum bahwa fasilitas sekolah yang lengkap sangat membantu dalam proses belajar mengajar. Termasuk sangat membantu peran guru menjalankan dan menerapkan perannya sebagai fasilitator.

d. Faktor kebiasaan lama guru dalam mengajar terlalu kuat

Faktor ini sangat memengaruhi gaya guru saat mengajar, kebiasaan lama guru saat mengajar memengaruhi secara kuat. Guru sudah terbiasa mengajar dengan mendikte sehingga butuh penyesuaian dan waktu yang lama untuk meninggalkan cara lama.

e. Kurangnya guru melakukan studi banding ke sekolah - sekolah yang di anggap telah berhasil menerapkan peran guru sebagai fasilitator.

Minimnya minimnya studi banding berdampak pada tidak adanya bandingan yang di peroleh guru seperti apa sesungguh dan seharusnya guru guru sebagai fasilitator itu dan bagaimana prinsip-prinsip yang harus di jalankan oleh guru (Agustina, 2017).

\section{Motivasi dan perananya dalam belajar}

\section{Pengertian motivasi}

Dalam dunia pendidikan masalah motivasi selalu menjadi hal yang menarik perhatian. Hal ini di karenakan motivasi di pandang sebagai salah satu faktor yang sangat dominan dalam ikut menentukan tercapai atau tidaknya tujuan pendidikan. Motivasi berasal dari kata motif yang bermakna suatu keadaan, kebutuhan atau dorongan yang disadari atau tidak disadari yang membawa kepada terjadinya suatu perilaku.

Motif merupakan suatu kondisi intern atau disposisi kesiap siagaan (Azwar, 2000). sedangan motivasi adalah daya penggerak yang telah menjadi aktif, dan motif menjadi aktif pada saat tertentu, bila kebutuhan untuk mencapai tujuan sangat dirasakan dan dihayati.

Motivasi belajar yaitu keseluruhan daya penggerak psikis di dalam diri siswa yang menimbulkan kegiatan belajar, menjamin kelangsungan kegiatan 
belajar dan memberi arah pada kegiatan belajar itu demi mencapai suatu tujuan (Winkel, 2005).

Jadi motivasi belajar adalah suatu penggerak yang timbul dari kekuatan mental dari dalam diri peserta didik untuk mencapai tujuan - tujuan belajar itu sendiri.

\section{Peran Guru dalam memotivasi peserta didik}

Guru memiliki peranan yang sangat penting dalam membangun motivasi peserta didik, terutama motivasi dalam kegiatan belajar. Memotivasi peserta didik merupakan hal yang sangat penting bagi guru. Untuk melakukan kegiatan tersebut, guru harus memahami peserta didik dengan baik, dan menyediakan pengalaman pembelajaran yang sesuia dengan peserta didik. Melalui pemahaman yang baik tentang peserta didik guru mampu mendorong peserta didik menemukan sesuatu yang menarik, bernilai dan secara instrinsik memotivasi, menantang, dan berguna bagi peserta didik. Semakin baik pemahaman guru tentang kebutuhan dan minatyang di miliki peserta didik, semakin mudah baginya untuk memotivasi peserta didik (Priansa, 2017).

Pemahaman mengenai peserta didik harus di dasarkan atas sejumlah informasi penting terkait dengan peserta didik itu sendiri. Untuk memberikan motivasi kepada peserta didik, guru dapat menggali informasi tentang hal-hal berikut.

a. Seperti apa orang dewasa cerdas, pemahaman peserta didik tentang orang dewasa yang cerdasmemberikan panduan tentang figur orangseperti apa yang menjadi teladannya.

b. Apa minat, hobi, dan cara - cara favorit untuk menghabiskan waktu Anda? Pertanyaan ini bisa menghantarkan guru untuk menggali informasitentang hal hal yang membuat peserta didik nyaman dan kegiatan apa saja yang di lakukan yang di lakukan peserta didik untuk menghabiskan waktunya.

c. Keterampilan, bakat, aktivitas, atau sesuatu yang membuat Anda menikmatinya? Pemahaman ini menggali informasi tentang potensi yang bisa dikembangkan diri pesrta didik.

d. Apa yang sangat tidak Anda sukai? Pertanyaan ini menggali informasi tentang segala hal yang tidak disukai oleh peserta didik.

e. Apa yang paling Anda takuti? Pertanyaan ini menggali informasi tentang apa saja yang di hindari oleh peserta didik (Siccone, 2001).

Selain perlu memahami peserta didik dengan baik, dalam memotivasi peserta didik koma guru pun harus mampu berkolaborasi dengan orang tua peserta didk. 
Kerjasama yang saling mendukung antara guru dan orang tua peserta didik sangat dibutuhkan karena orang tua peserta didik merupakan sosok yang paling ideal yang berangkat dari rumah. Orang tua peserta didik dapat mengembangkan komunikasi positif dengan anaknya sehingga dalam diri anak tertanam nilai-nilai positif yang akan menjadi bekal baginya ketika hidup di tengah masyarakat, terutama dalam pergaulan di sekolah. Orang tua peserta didik yang mampu memotivasi anaknya dengan positif di rumah akan mendorong anaknya untuk berperilaku positif di tengah-tengah masyarakat (Priansa, 2017).

Guru yang profesional harus mampu menggali segala hal yang mampu memotivasi peserta didik. Sering guru memberikan tugas belajar yang tidak diminati oleh peserta didik dan tidak mampu membangkitkan minat peserta didik sehingga peserta didik menjadi malas dan bosan melaksanakan tugas tersebut. Ini menjadi tantangan tersendiri bagi guru. Sesukar apapun tugas yang diberikan oleh guru bagi peserta didik, guru harus melengkapi nya dengan motivasi yang tepat sehingga peserta didik akan termotivasi dan mampu mengikuti proses belajar dengan optimal.

Selain itu, guru harus mampu meyakinkan peserta didik dan mengajak peserta didik dalam proses belajar yang bermakna bagi peserta didik itu sendiri. Mereka harus diberi kesadaran yang memadai dan dilakukan secara bertahap bahwa belajar itu penting baginya dan penting bagi masa depan yang ingin diraihnya. Guru harus mampu meyakinkan bahwa setiap waktu yang mereka habiskan dalam belajar akan memperoleh hasil pada masa depan.

Semakin banyak prestasi atau kesuksesan yang diperoleh oleh peserta didik, semakin besar pula kesempatan peserta didik untuk meraih harapan pada masa depan, dan hal tersebut juga memotivasi peserta didik untuk mampu menyelesaikan tugas yang lebih sukar, yang artinya peserta didik diberikan kesempatan untuk naik tingkat lebih tinggi (Schunk, 2002). Penelitian tersebut menunjukkan bahwa motivasi merupakan variabel yang lebih penting daripada kemampuan peserta didik itu sendiri.

\section{Pembelajaran Pendidikan Agama Islam}

\section{Pengertian Pembelajaran PAI}

Menurut Corey sebagaimana dikutip oleh Syaiful Sagala, Pembelajaran adalah suatu proses dimana lingkungan seseorang secara disengaja dikelola untuk memungkinkan ia turut serta dalam tingkah laku tertentu dalam kondisi - kondisi khusus atau menghasilkan respon terhadap situasi tertentu, pembelajaran merupakan subset khusus dari pendidikan. (Sagala, 2003) 
Pembelajaran merupakan aktualisasi kurikulum yang menuntut guru dalam menciptakan dan menumbuhkan kegiatan kegiatan peserta didik sesuai dengan rencana yang telah diprogramkan (E.Mulyasa, 2006).

Jadi pembelajaran adalah proses yang disengaja dirancang untuk menciptakan terjadinya kegiatan belajar dalam diri individu. Atau bisa juga pembelajaran adalah suatu hal yang bersifat diluar atau eksternal yang sengaja dirancang untuk mendukung terjadinya proses belajar internal dalam diri individu.

Salah satu tujuan Pendidikan Agama Islam secara umum yang tercantum dalam keputusan menteri agama R.I. nomor 211 tahun 2011 adalah untuk berkembangnya kemampuan peserta didik dalam memahami,menghayati serta mengamalkan nilai-nilai Agama Islam dan menyerasikan penguasaanya ke dalam ilmu pengetahuan, teknologi dan seni (KEMENAG, 2011).

Menurut Arifin yang dikutip oleh Akmal Hawi, mengemukakan bahwa tujuan Pendidikan Agama Islam adalah "membina dan mendasari kehidupan anak dengan nilainilai syari'at Islam secara benar sesuai dengan pengetahuan agama” (Hawi, 2014).

Sedang menurut Muhaimin, bahwa tujuan Pendidikan Agama Islam bertujuan untuk meningkatkan keimanan, pemahaman, penghayatan, dan pengalaman peserta didik tentang agama Islam, sehingga menjadi manusia muslim yang beriman dan bertakwa kepada Allah Swt serta berakhlak mulia dalam kehidupan pribadi, bermasyarakat, berbangsa dan bernegara (Muhaimin,2004). Tujuan Pendidikan Agama Islam di sekolah adalah untuk:

a. Meningkatkan keimanan dan ketakwaan pada Allah SWT dalam diri peserta didik melalui pengenalan, pemahaman, penghayatan terhadap ayat-ayat Allah yang tercipta dan tertulis (ayat kauniyyah dan ayat qauliyyah).

b. Membentuk karakter muslim dalam diri peserta didik melalui pengenalan, pemahaman, dan pembiasaan norma-norma dan aturan-aturan Islam dalam melakukan relasi yang harmonis dengan Tuhan, diri sendiri, sesama, dan lingkungannya.

c. Mengembangkan nalar dan sikap moral yang selaras dengan keyakinan Islam dalam kehidupan sebagai warga masyarakat, warga negara, dan warga dunia (KEMENAG, 2011).

\section{Fungsi PAI}


Fungsi Pendidikan Agama Islam dalam keputusan menteri agama R.I. nomor 211 tahun 2011, tentang pedoman pengembangan standar nasional Pendidikan Agama Islam pada sekolah adalah sebagai berikut:

a. Penanaman nilai ajaran Islam sebagai pedoman mencapai kebahagiaan hidup di dunia dan akhirat.

b. Peningkatan keimanan dan ketakwaan kepada Allah SWT serta akhlak mulia peserta didik seoptimal mungkin, yang telah ditanamkan lebih dahulu dalam lingkungan keluarga.

c. Penyesuaian mental peserta didik terhadap lingkungan fisik dan sosial.

d. Perbaikan kesalahan, kelemahan peserta didik dalam keyakinan, pengalaman ajaran Agama Islam dalam kehidupan sehari-hari.

e. Pencegahan peserta didik dari dampak negatif budaya asing yang dihadapi seharihari.

f. Pengajaran tentang ilmu keagamaan baik teori maupun praktik.

g. Penyaluran bakat-minat peserta didik di bidang Keislaman; dan

h. Penyelarasan antara potensi dasar (fithrah mukhallaqah) peserta didik dengan agama (fithrah munazzalah) sebagai acuan hidup agar peserta didik tetap berjalan di atas nilai-nilai Islam.

Dari uraian di atas dapat di simpulkan bahwa fungsi Pendidikan Agama Islam adalah menjaga dan memelihara fitrah manusia menuju terbentuknya manusia yang berkepribadian mulia serta pengagung Tuhan yang Maha Pencipta, yaitu manusia yang istiqomah menjalankan perintah Agama Islam untuk membimbing dalam kehidupan sehari-hari, serta sebagai pedoman untuk menuju kebahagiaan yang hakiki yaitu kehidupan akhirat, dan saling menasehati sesama manusia dalam kebenaran dan kesabaran sebagai pencegahan dari perbuatan yang tidak sesuai dengan norma Agama Islam.

\section{Kesimpulan}

Guru PAI memberikan motivasi dengan menanyakan kepada peserta didik sebelum dimulainya pembelajaran dengan pertanyaan yang terkait dengan ibadah sholat shubuh apakah dilaksanakan ataukah tidak, kemudian ditambah pertanyaan terkait ibadah Tadarus Al-Quran sering dibaca ataukah tidak. Dalam menerapkan motivasi beribadah peserta didik, guru PAI menambahkan berupa buku Kegiatan Ibadah Dirumah, dengan maksud untuk memotivasi kegiatan keagamaan dirumah agar dijalankan dengan baik. Berkaitan dengan 
pembelajaran dikelas guru berupaya menghadirkan susana pembelajaran yang menyenangkan ditambah dengan Ice Breaking pada saat jam pelajaran akhir.

\section{Daftar Pustaka}

Azwar, S. (2000). Realibitas dan Validitas. Yogyakarta: Pustaka Belajar.

Achmadi. Ideologi Pendidikan Islam Paradigma Humanisme Teosentris.

Yogyakarta: Pustaka Pelajar. 2005.

E.Mulyasa, M. (2006). Kurikulum Tingkat Satuan Pendidikan. Bandung: Remaja Rosdakarya.

Khadijah, N. (2011). Psikologi Pendidikan . palembang: Grafika Telindo Press.

Priansa, D. J. (2017). Menjadi Kepala Sekolah dan Guru Profesional. Bandung: Pustaka Setia.

Priansa, D. J. (2017). Menjadi Kepala Sekolah dan Guru Profesional. Bandung: Pustaka Setia.

Sagala, S. (2003). Konsep dan Makna Pembelajaran. Bandung: Alfabeta.

Sanjaya, W. (2008). Strategi Pembelajaran Berorientasi Pada Proses Pendidikan. Jakarta: Kencana Prenada Group.

Subhan Adi Santoso, Ali Mustofa, 2019. Ilmu Pendidikan Islam Era Industri 4.0. Malang: Media Sutra Tiga

Subhan Adi Santoso, Maulidyah Amalina Rizqi 2020. Kinerja Pengawas Sekolah, Kepala Sekolah, dan Guru pada Pendidikan. Yogyakarta: Deepublish

Schunk, P. P. (2002). Motivation in Education: Theory, Research, and Applications. New Jersey: Prentice Hall.

Siccone, H. M. (2001). Motivating Your Students. Boston: Allyn and Bacon.

Sindhunata. (2001). Pendidikan, Kegelisahan Sepanjang Zaman. Yogyakarta: Kanisius.

Surya, M. (2004). Psikologi Pembelajaran dan Pengajaran. Yogyakarta: Pustaka Bani Quraisy.

Winkel, W. (2005). Psikologi Pengajaran. Jakarta: Gramedia Pustaka Tama. 